\title{
Vegetation recovery in fire-damaged forests: a case study at the southern boundary of the taiga zone
}

\author{
Anatoliy A. Khapugin ${ }^{1,2, *}$, Elena V. Vargot ${ }^{1,2,3}$, \\ Gennadiy G. Chugunov ${ }^{1,2,3}$
}

\begin{abstract}
Khapugin, A.A., Vargot, E.V., Chugunov, G.G. 2016. Vegetation recovery in firedamaged forests: a case study at the southern boundary of the taiga zone. - Forestry Studies | Metsanduslikud Uurimused 64, 39-50. ISSN 1406-9954. Journal homepage: http:// mi.emu.ee/forestry.studies
\end{abstract}

\begin{abstract}
Wildfire is regarded as important environmental factor determining the vegetation of the Earth. We analyzed 11 plots at different types of forest affected by fire at the southern boundary of the taiga zone. These differ in structure of the forest stand and herb-shrub layer. Investigated factors included edaphic (moisture, $\mathrm{pH}$, nitrogen) and climatic (light, temperature, continentality) characteristics. Also, projective cover of Epilobium angustifolium L. and undergrowth of secondary growth trees (including forest stand survived after fire influence) were studied. Multivariate data analysis revealed that the rate and character of the vegetation recovery was depended on the ratio of environmental factors and on the species composition of herb-shrub layer. No significant differences were found in Ellenberg's indicator values between different years of study. All tested forest habitats were distinguished into three main groups: Group I includes broadleaf forests with the forest stand survived after fire influence, Group II includes spruce and birch forests deprived the forest stand due to fire impact, Group III includes more or less dry pine-dominated forests with the forest stand gradually died after fire influence. Two marshy plots have prerequisites to their allocation to a separate group close to the oligotrophic bog forests.
\end{abstract}

Key words: Ellenberg's indicator values, wildfire, environmental factors, post-fire succession, projective cover, ordination, taiga zone, Mordovia State Nature Reserve.

Authors' addresses: ${ }^{1}$ Mordovia State Nature Reserve, 431230, Pushta, Temnikov district, Republic of Mordovia, Russia; ${ }^{2}$ Department of Botany, Physiology and Ecology of Plants, Mordovia State University, 430005, Bolshevistskaya Street, 68, Saransk, Republic of Mordovia, Russia; ${ }^{3}$ National Park "Smolny", 431660, Topoley Street, 11, Smolny, Ichalki district, Republic of Mordovia, Russia; *e-mail: hapugin88@yandex.ru

\section{Introduction}

Fires arise from a combination of abiotic (ignition source) and biotic (adequate fuel) conditions subject to climate forcing. Fire interactively links atmosphere, biosphere, and human Earth system components through time and at local, regional and global spatial scales (Lavorel et al., 2007). In some regions of the world, e.g. South-Eastern Australia, South Africa, fire is inherent to ecosystem dynamics. Plants of these ecosystems are adapted to periodic fires; some of them even rely on these recurring events (Walter \& Breckle, 1999). Here fire is necessary to maintain the ecological balance. Fire disturbances are common in European temperate and boreal natural forests (Ulanova, 2000). Fire is an important environmental factor determining the vegetation cover. Due to the human activity, its impact has significantly increased (Hytteborn 
et al., 2005). The forest fire has a short but powerful damaging effect on plants. Depending on the intensity of the fire, most vegetation and the forest litter are burnt up to cases where a particularly strong surface fire also partially destroys the soil (Bond \& Wilgen, 1996; Gromtsev, 2000; Summers et al., 2011). Due to the fire impact, the competition conditions in forest plant communities are altered completely due to shortterm mobilization of nutrients, which supports plant growth. Different forest types are different in relation to sensibility to fire impact (Tinner et al., 2000) and to natural regeneration (Karami et al., 2014).

The characteristics of the forest abiotic environment covered by these units are referred to as "permanent environmental conditions" (Viewegh et al., 2003). However, these characteristics can show the current scale of disturbance (Steffen et al., 2011; Zhang et al., 2015). Plants often reflect temporally integrated environmental conditions and are therefore particularly useful indicators when values averaged over time are needed (ter Braak \& Gremmen, 1987). Often, European scientists use an average Ellenberg's Indicator Values (EIVs) to demonstrate and compare the influence of environmental factors in the different forest types. EIVs and their regional adjustments (Hill et al., 1999; Ellenberg et al., 2001; Böhling et al., 2002; Pignatti et al., 2005; Seregin, 2014) are the most popular indicator values in both national and local studies, although results of these studies are sometimes questioned (Godefroid \& Dana, 2007) or considered as "too good to be true" (Zelený \& Schaffers, 2012). Also Ellenberg's ecological scale is used in investigations related to fire impact on the forest ecosystem and its consequences (Vacchiano et al., 2015).

The aim of the present study was to analyze the abiotic environment factors and re-vegetation dynamics in the firedamaged forest areas at the southern boundary of the taiga zone using phytoindication method. We focused on following questions: (I) what components of forest ecosystem could be indicators of the way of vegetation recovery? (II); what environmental factors could be considered as the most important in the post-fire successions at the southern boundary of the taiga zone?

\section{Material and Methods}

\section{Study area and sampling}

The Mordovia State Nature Reserve is situated in the southern boundary of the taiga natural zone $\left(54^{\circ} 42^{\prime}-54^{\circ} 56^{\prime} \mathrm{N} 43^{\circ} 04^{\prime}\right.$ $43^{\circ} 36^{\prime} \mathrm{E}$; up to $190 \mathrm{~m}$ a.s.l., Figure 1), in Central Russia. Total area of the Mordovia Reserve is 321.62 sq. km. Forest communities cover $89.3 \%$ of total reserve area. Soils are classified as predominantly sand in varying degree of podzolization. These lie on the ancient alluvial sands. Sandy peaty podzolic soils are also widely spread on sands with a fairly high level of ground water. Sandy podzolized soils are located under deciduous forests. Easily loamy soils are distributed in same conditions but much less frequently (Kuznetsov, 2014). The mean annual precipitation in this area varies from 406.6 to $681.3 \mathrm{~mm}$ dependent on year. The mean annual air temperature is $4.7^{\circ} \mathrm{C}$. Maximal temperature values are registered in July, and minimal - in February (Bayanov, 2015). The vegetation cover of the Mordovia Reserve is similar to the taiga complex with some features numeral communities. Participation of foreststeppe elements is also typical for this area (Tereshkin \& Tereshkina, 2006).

In 2010, forests of the Mordovia Reserve were burned; about $30 \%$ of the forest was damaged by fire (pers. obs.). Geobotanical methodic follows Aleksandrova (1964). To study the post-fire succession of vegetation cover in the Mordovia State Nature Reserve, we randomly established 11 square plots $(100 \times 100 \mathrm{~m})$ in the most typical forest habitats damaged by wildfire in 2010 . Of these, five plots were established in pine (Pinus sylvestris L.) forests (Pin07, Pin26, 


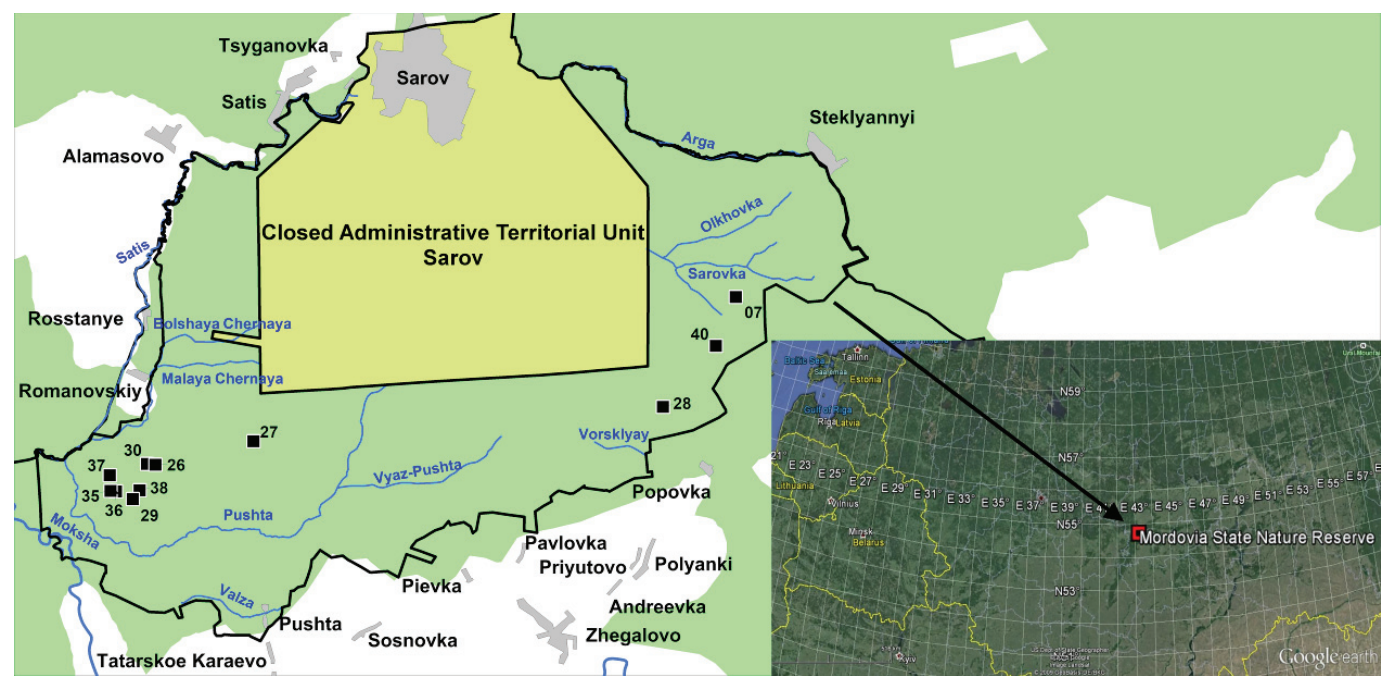

Figure 1. Geographical position of the Mordovia State Nature Reserve in Eastern Europe. Numbers on map of the Mordovia Reserve indicate the established plots referred to in the list of studied locations.

Pin27, Pin38, Pin40), two in spruce (Picea abies (L.) H.Karst.) forests (Pic28, Pic29), two in oak (Quercus robur L.) forests (Que36, Que37), one in birch (Betula pendula Roth) forest (Bet30) and one in lime (Tilia cordata Mill.) forest (Til35) (Khapugin et al., 2012). We investigated the species composition of flora and the projective cover of each plant species within all studied plots in 2011-2015 years. A characteristic of wildfire in 2010 year is presented in Table 1. Percentage of the fire-damaged forest area was assessed visually. Fire severity was assessed according to Ryan (2002) and Turner et al. (1994) with modifications. Assessment of the fire intensity was carried out according to the Fire Intensity Risk System (BC Wildfire Service, 2015). Eight of established plots were studied from 2011 to 2014. Plots Pin07 and Pin40 were established only in 2014. Plot Pic28 was studied in 2012 and 2014 years.

We investigated the dynamics of the projective cover of two constant and wellknown members of secondary post-fire successions. We selected Epilobium angustifolium L. and undergrowth of secondary growth trees (B. pendula, Populus tremula
L., Alnus glutinosa (L.) Gaertn.) (including cover of tree canopy) as a widely known and recognizable participants of post-fire succession in boreal forests (Ruokolainen \& Salo, 2006; Lentile et al., 2007; Nowak et al., 2002). Whereas the role of E. angustifolium and secondary growth trees are well-known, there is lack of data on the relationships of these during the early stages of postfire successions. That's why we analyzed data only for those established plots where investigations were carried out directly from 2011 to 2015. Thus, plots Pn07, Pn40, Pc28 were excluded from analysis.

\section{Ellenberg's indicator values and statistical analysis}

The third edition of EIVs (Ellenberg et al., 2001) includes data on the most species revealed within established plots. Based on the species composition of flora within each established plot (Khapugin et al., 2012), we calculated the mean EIVs weighted by species cover (weighted mean; Diekmann, 2003) for six environment factors (light (L), temperature $(\mathrm{T})$, continentality $(\mathrm{C})$, moisture $(\mathrm{M}), \mathrm{pH}(\mathrm{R})$, nutrient availability $(\mathrm{N})$ ) 
Table 1. Characteristic of the wildfire in 2010 per each established plot.

\begin{tabular}{lccc}
\hline Plots & $\begin{array}{c}\text { Percent of } \\
\text { area burned, } \%\end{array}$ & Severity & Intensity \\
\hline Pn07 & 90 & Severe surface burn & 3 (Moderately vigorous surface fire) \\
Pn26 & 95 & Severe surface burn & 3 (Moderately vigorous surface fire) \\
Pn27 & 100 & Crown fire & 5 (Extremely vigorous surface fire or active \\
crown fire)
\end{tabular}

to show which environment factors determine the path of vegetation recovery in different habitats during the early stages (2011-2015 years) of pyrogenic succession. In EIV calculation, let $r_{i j}$ be the response of species $i$ in sample plot $j$, and $x_{i}$ is the indicator value of species $i$. Then, weighted mean of all values of those plant species presented in the plot was calculated to estimate the EIV:

$$
\text { Average mean }=\sum_{i=1}^{n}\left(r_{i j} * x_{i}\right) / \sum_{i=1}^{n} r_{j}
$$

\section{Data analysis}

Statistical analysis was performed in MS Excel and PAST (Hammer et al., 2001). Spearman-Rank correlations were calculated to assess correlations of mean EIVs by years of study. The ordination techniques, using the detrended correspondent analysis (DCA), defined the major gradients in the spatial arrangement of studied habitats of the analysed data set. For ecological interpretation of the ordination axes, average
EIVs (Ellenberg et al., 2001) for established plots were plotted onto a DCA ordination diagram as supplementary environmental data.

\section{Results}

\section{Mean EIVs for established plots}

Different mean EIVs had different variance for the entire set of established forest plots (Figure 2).

Mean EIVs had different amplitude of values (Figure 2). Mean N-, R- and M-values had been varied more than other environmental factors. Hence we can suggest that these factors are the most significant in determining of differences in vegetation recovery on plots tested. Also, light gradient was relatively variable.

This assumption is confirmed by the detrended correspondence analysis (DCA) of total number EIVs (including all environmental factors and years of study for all established plots). Biplot arrows (Figure 3) showed the maximum and strength of cor- 


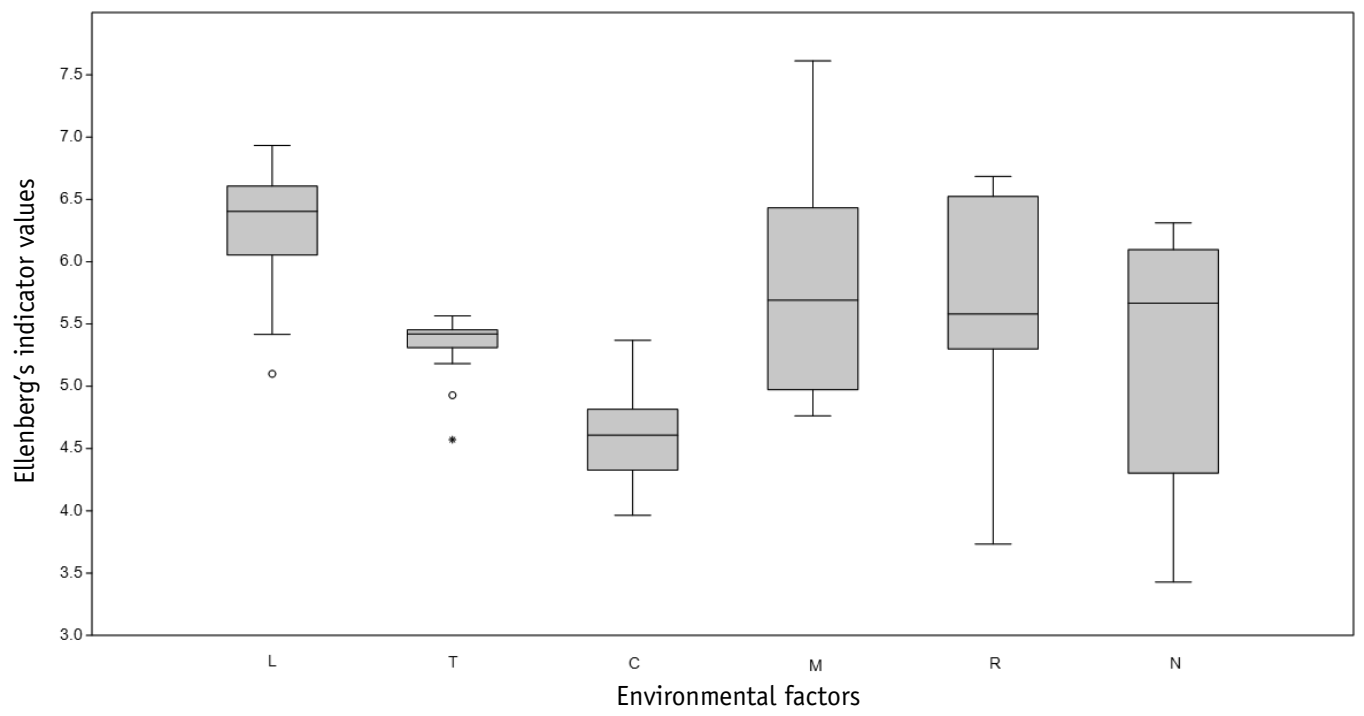

Figure 2. Boxplots of mean Ellenberg's indicator values for the entire set of established plots at the southern boundary of the taiga zone; $L$ - light, $T$ - temperature, $C$ - continentality, $M$ - soil moisture, $\mathrm{R}$ - soil pH, $\mathrm{N}$ - soil nitrogen.

relation for edaphic conditions $(\mathrm{pH}$, moisture, fertility) while light gradient was most significant only for isolation of broadleaved forest communities. EIVs, plotted onto ordination diagram, revealed that the major compositional gradient in firedamaged forests positively correlates with edaphic conditions ( $\mathrm{pH}$, moisture, fertility) and temperature, and negatively with light and continentality. Thus major variation in species composition of the fire-damaged forests of the Mordovia State Nature Reserve corresponds to the combination of several gradients.

DCA showed differentiation of all tested forest communities into three main groups (I, II, III). In contrast, forest plots Pn04 and Pn40 are located significantly separately from other (Figure 3). Plots at broad-leaved forest communities belonged to Group I due to more eutrophic and basic soil conditions and poor light conditions. Due to last fact Group I differs of other plots where forest canopy was predominantly lost. Group II included both coniferous (Piceetum) and deciduous (Betuletum) forest communities. All of these are characterized by moderately acid and more or less moist (from fresh to moist or damp) soils. Group III included the most dry and nitrogen-poor with relatively acidic soils. All these are pine-dominated forest communities. Of these, plot Pn27 is located in more upper-right position. Mean EIVs in different years were very similar within each tested plot (Table 2).

\section{Changes in projective cover for several plant species during the period of 2011- 2015}

In almost all cases, the projective cover of E. angustifolium was being decreased from 2011 to 2015 (Figure 4). Rate of this process had different rate depending of forest habitat. In contrast, the total projective cover of a tree canopy (forest stand plus secondary growth trees) was being increased or it remained almost unchanged or this decrease was insignificant. The figure 4 shows that the curve's structure for projective cover of E. angustifolium and secondary growth trees (with forest stand) depends on the 
Table 2. Spearman-Rank correlations of different years of study in space of mean Ellenberg's indicator values for each tested forest plot at the southern boundary of the taiga zone.

\begin{tabular}{|c|c|c|c|c|c|}
\hline \multicolumn{6}{|c|}{ Pn26 } \\
\hline & 2011 & 2012 & 2013 & 2014 & 2015 \\
\hline 2011 & & 0.943 & 0.943 & 0.943 & 0.829 \\
\hline 2012 & & & 1.000 & 1.000 & 0.943 \\
\hline 2013 & & & & 1.000 & 0.943 \\
\hline 2014 & & & & & 0.943 \\
\hline 2015 & & & & & \\
\hline \multicolumn{6}{|c|}{ Pn27 } \\
\hline & 2011 & 2012 & 2013 & 2014 & 2015 \\
\hline 2011 & & 0.899 & 0.986 & 0.986 & 0.986 \\
\hline 2012 & & & 0.943 & 0.943 & 0.943 \\
\hline 2013 & & & & 1.000 & 1.000 \\
\hline 2014 & & & & & 1.000 \\
\hline 2015 & & & & & \\
\hline \multicolumn{6}{|c|}{ Pn38 } \\
\hline & 2011 & 2012 & 2013 & 2014 & 2015 \\
\hline 2011 & & 0.886 & 0.886 & 0.886 & 0.886 \\
\hline 2012 & & & 1.000 & 1.000 & 1.000 \\
\hline 2013 & & & & 1.000 & 1.000 \\
\hline 2014 & & & & & 1.000 \\
\hline 2015 & & & & & \\
\hline \multicolumn{6}{|c|}{ Pc28 } \\
\hline & & \multicolumn{2}{|c|}{2012} & \multicolumn{2}{|c|}{2014} \\
\hline 2012 & & & & \multirow{2}{*}{\multicolumn{2}{|c|}{0.829}} \\
\hline 2014 & & & & & \\
\hline \multicolumn{6}{|c|}{ Pc29 } \\
\hline & 2011 & 2012 & 2013 & 2014 & 2015 \\
\hline 2011 & & 1.000 & 1.000 & 1.000 & 1.000 \\
\hline 2012 & & & 1.000 & 1.000 & 1.000 \\
\hline 2013 & & & & 1.000 & 1.000 \\
\hline 2014 & & & & & 1.000 \\
\hline 2015 & & & & & \\
\hline \multicolumn{6}{|c|}{ Bt30 } \\
\hline & 2011 & 2012 & 2013 & 2014 & 2015 \\
\hline 2011 & & 1.000 & 1.000 & 1.000 & 0.943 \\
\hline 2012 & & & 1.000 & 1.000 & 0.943 \\
\hline 2013 & & & & 1.000 & 0.943 \\
\hline 2014 & & & & & 0.943 \\
\hline 2015 & & & & & \\
\hline \multicolumn{6}{|c|}{ Qu36 } \\
\hline & 2011 & 2012 & 2013 & 2014 & 2015 \\
\hline 2011 & & 1.000 & 1.000 & 1.000 & 1.000 \\
\hline 2012 & & & 1.000 & 1.000 & 1.000 \\
\hline 2013 & & & & 1.000 & 1.000 \\
\hline 2014 & & & & & 1.000 \\
\hline 2015 & & & & & \\
\hline \multicolumn{6}{|c|}{ Qu37 } \\
\hline & 2011 & 2012 & 2013 & 2014 & 2015 \\
\hline 2011 & & 0.943 & 0.943 & 0.943 & 0.943 \\
\hline 2012 & & & 1.000 & 1.000 & 1.000 \\
\hline 2013 & & & & 1.000 & 1.000 \\
\hline 2014 & & & & & 1.000 \\
\hline 2015 & & & & & \\
\hline \multicolumn{6}{|c|}{ Ti35 } \\
\hline & 2011 & 2012 & 2013 & 2014 & 2015 \\
\hline 2011 & & 1.000 & 1.000 & 0.943 & 0.943 \\
\hline 2012 & & & 1.000 & 0.943 & 0.943 \\
\hline 2013 & & & & 0.943 & 0.943 \\
\hline 2014 & & & & & 1.000 \\
\hline 2015 & & & & & \\
\hline
\end{tabular}

affiliation of habitat to one of groups recognized on the basis of DCA for environment factors (Figure 3).

Figure 4 shows that in most cases the projective cover of $E$. angustifolium negatively correlated with those of secondary growth trees (with forest stand). So, projective cover of E. angustifolium at established plots of the Group I was not higher than $17 \%$ that correlates with constantly high the projective cover of secondary growth trees (with forest stand). On plots of Group II, projective cover of E. angustifolium continuously was decreased, and, in contrast, projective cover of secondary growth trees (with forest stand) was increased in period of 2011-2015. Group III is more heterogeneous in compare with other distinguished habitat groups (Figure 3). Of these, plots Pn26 and Pn38 characterized by more or less slightly defined peak on the graphic of changes projective cover for E. angustifolium (correlated with the same decline of projective cover for secondary growth trees (with forest stand)). In case of a plot Pn27, the projective cover of both these succession components has increased up to approximately equal level.

\section{Discussion}

Mean Ellenberg's indicator values for nitrogen, moisture and $\mathrm{pH}$ have changed significantly among tested plots. Of these, soil nitrogen was spatially correlated positively with moisture and $\mathrm{pH}$, although soil moisture showed relatively low correlation with soil pH (Table 3, Figure 5). Additionally, light showed high positive correlation with continentality.

Groups of fire-damaged habitats were distinguished on the base of all selected environmental factors (Figure 3). Independence of these groups is supported by their own strategy of vegetation recovery within each group (Figure 4). Opportunity to this distinction is especially important due to mixed composition of many forest 


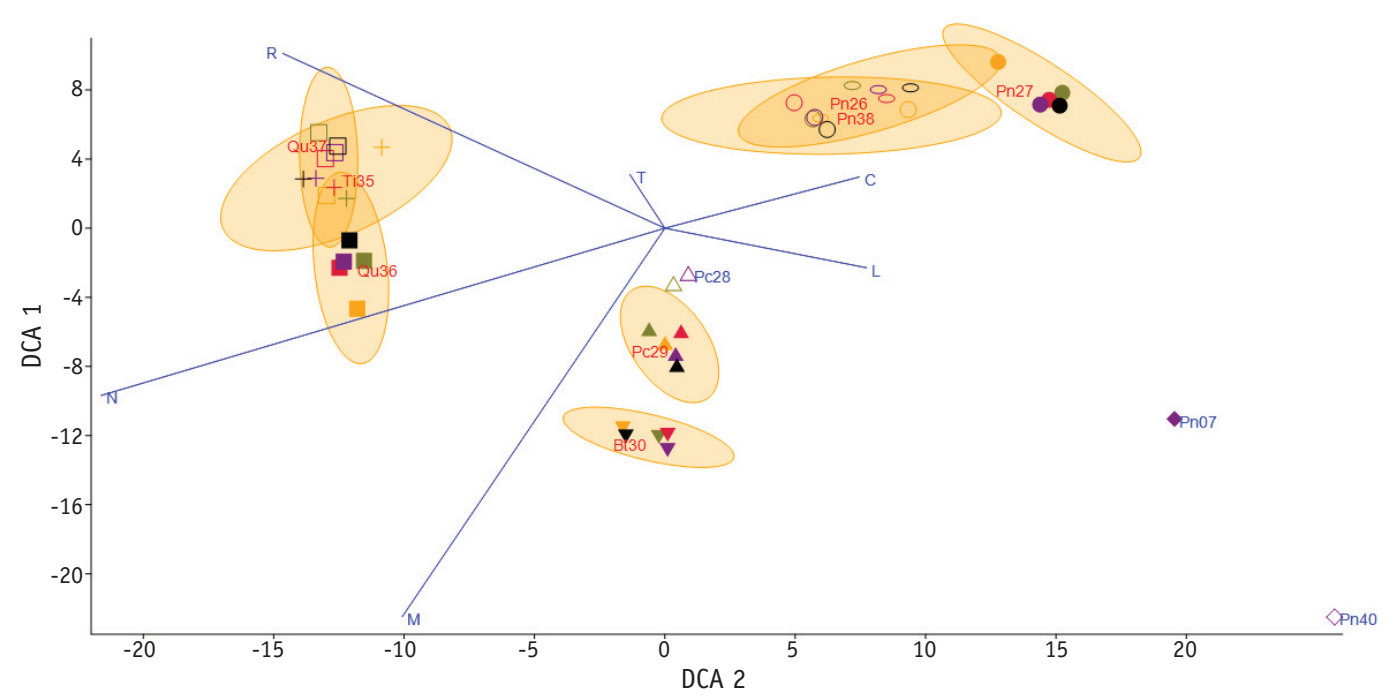

Figure 3. Detrended correspondence analysis (DCA) ordination diagram of plots established in forests at the southern boundary of the taiga zone. Symbols: square - Qu37, fill square - Qu36, + - Ti35, triangle - Pc28, fill triangle - Pc29, inv. triangle - Bt30, oval - Pn26, fill circle - Pn27, circle Pn38, diamond - Pn40, fill diamond - Pn07. Symbol's colors: $\square-2011$ year, $\square-2012$, - 2013, - 2014, - 2015. Environmental factors: L - light, T - temperature, C continentality, $\mathrm{M}$ - soil moisture, $\mathrm{R}$ - soil $\mathrm{pH}, \mathrm{N}$ - soil nitrogen. To reveal ecological gradients, mean Ellenberg's indicator values were plotted onto DCA ordination diagram as supplementary environmental variables.

ecosystems in conditions of the southern boundary of the taiga zone. In this ecotone, nemoral species (e.g. Carex pilosa Scop., Actaea spicata L.) can grow in boreal forest habitats while some boreal species (e.g. Oxalis acetosella L., Rubus nessensis Hall) can grow in nemoral forest ecosystems.

High similarity of habitats in Group I is generally explained mainly by low fire intensity (Table 1). Due to this fact, more (Ti35) or less (Qu36) large proportion of natural vegetation was less damaged by wildfire. That's why, native nemoral plants were occurred here during the investigation period (e.g., Glechoma hederacea L., C. pilosa, Stellaria holostea L., Lamium maculatum L.). Also, due to low fire intensity, projective cover of forest stand has insignificantly decreased or it has not changed. Perhaps this fact was reason for the low projective cover of E. angustifolium in these habitats.
The common feature of Group II is the full loss of the forest stand after fire influence and consequently is 4 degree of fire intensity (Table 1). Similarity of birch and spruce forests in this group has been significantly caused by similar and higher mean light and moisture EIVs due to the full loss of forest stand at these burned habitats. Absence of the overlapping of confidence ellipses $(90 \%)$ for these damaged habitats (Figure 3 ) is explained by expected differences in soil nitrogen and soil $\mathrm{pH}$. Low plant species competition and high light level have provided the intensive growth and high projective cover for E. angustifolium at first two years of study. During the increase of projective cover of secondary growth trees, projective cover and individuals' vitality $E$. angustifolium have decreased. 


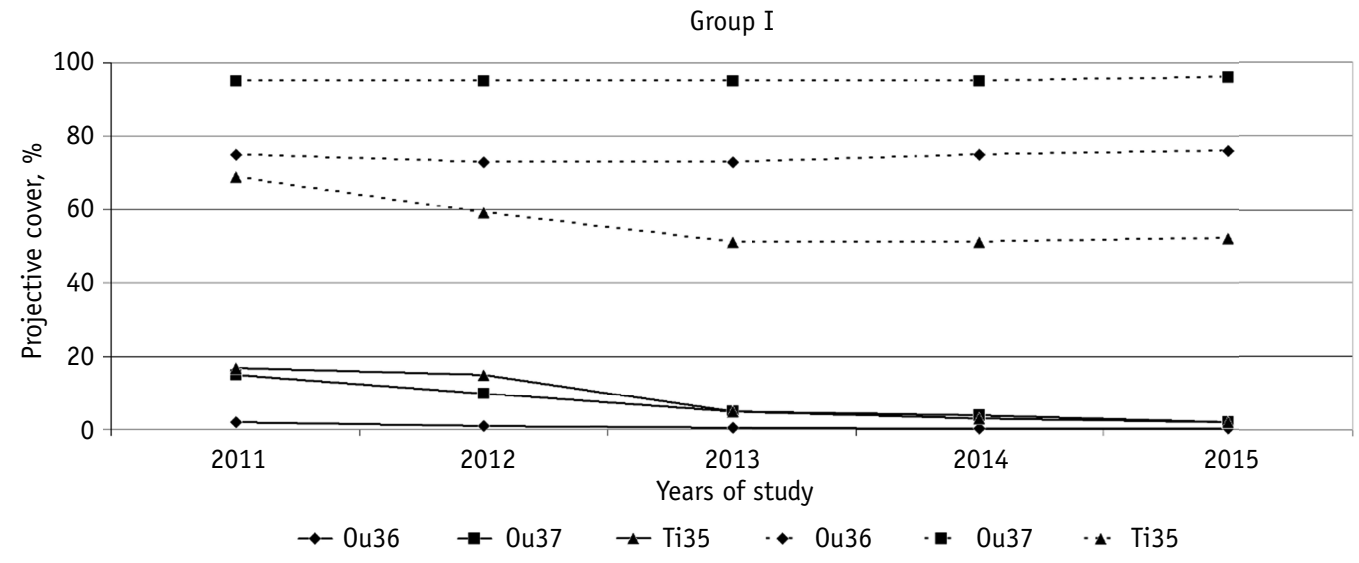

Group II

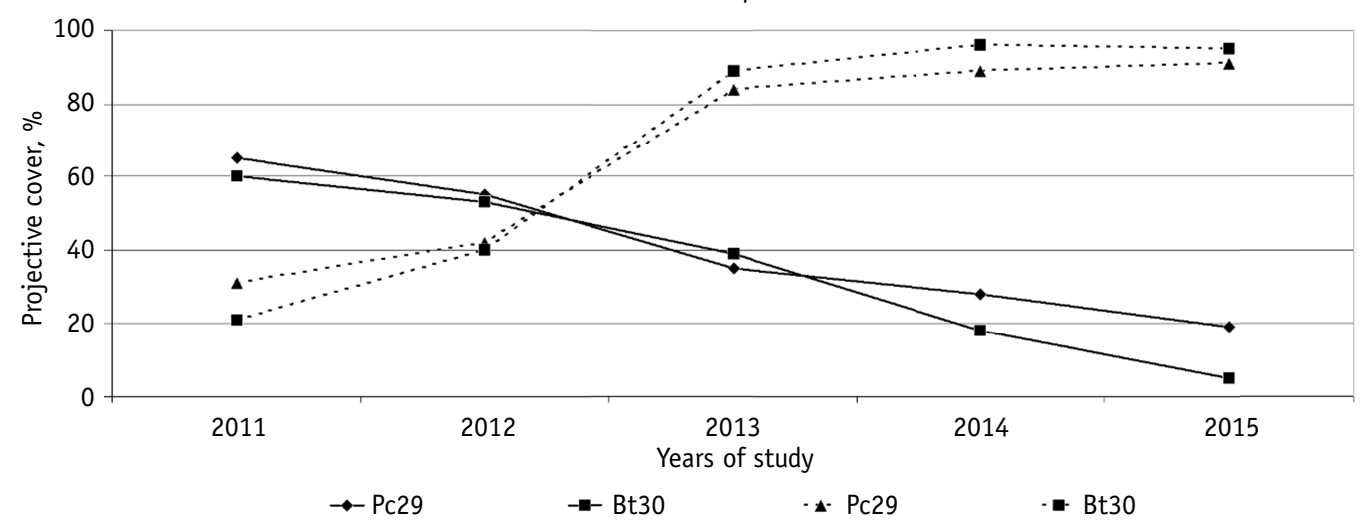

Group III

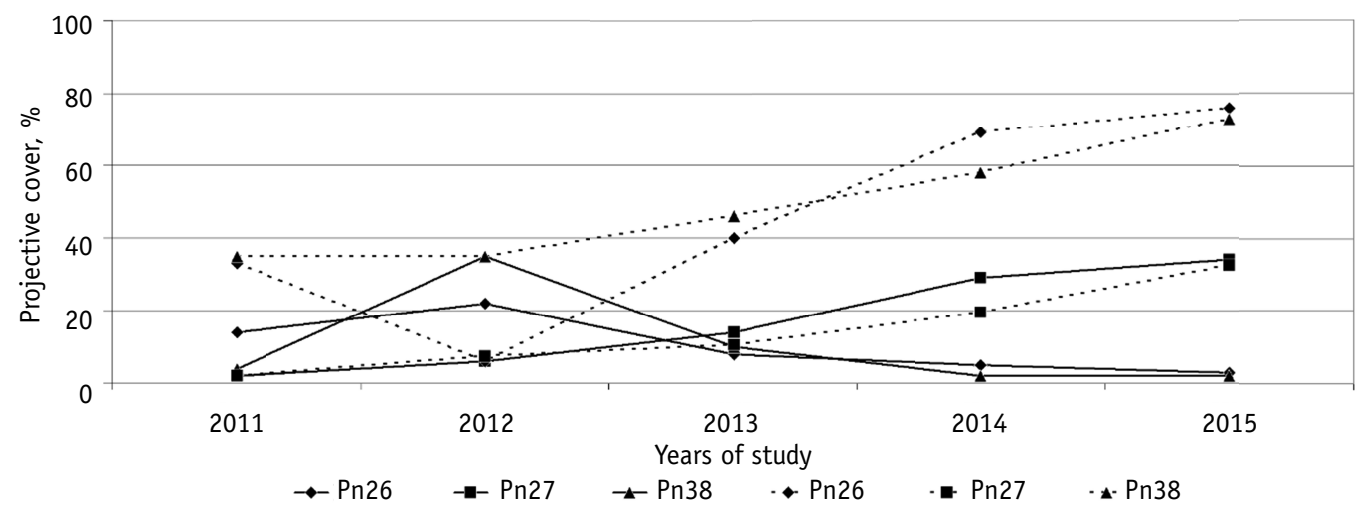

Figure 4. Dynamics of projective cover of Epilobium angustifolium (solid line) and undergrowth of secondary growth trees (Betula pendula, Populus tremula, Alnus glutinosa) (including the canopy of forest stand) (dotted line) at the southern boundary of the taiga zone over period of 2011-2015 years. 
Table 3. Spearman-Rank correlations of mean Ellenberg's indicator values (EIVs) for all tested forest plots at the southern boundary of the taiga zone. $\mathrm{L}$ - light, $\mathrm{T}$ temperature, $\mathrm{C}$ - continentality, $\mathrm{M}$ - soil moisture, $\mathrm{R}$ - soil $\mathrm{pH}, \mathrm{N}$ - soil nitrogen.

\begin{tabular}{ccccccc}
\hline EIVs & $\mathrm{L}$ & $\mathrm{T}$ & $\mathrm{C}$ & $\mathrm{M}$ & $\mathrm{R}$ & $\mathrm{N}$ \\
\hline $\mathrm{L}$ & & 0.173 & 0.669 & -0.176 & -0.609 & -0.655 \\
$\mathrm{~T}$ & 0.173 & & 0.035 & -0.159 & 0.241 & 0.070 \\
$\mathrm{C}$ & 0.669 & 0.035 & & -0.647 & -0.634 & -0.865 \\
$\mathrm{M}$ & -0.176 & -0.159 & -0.647 & & 0.188 & 0.687 \\
$\mathrm{R}$ & -0.609 & 0.241 & -0.634 & 0.188 & & 0.652 \\
$\mathrm{~N}$ & -0.655 & 0.070 & -0.865 & 0.687 & 0.652 & \\
\hline
\end{tabular}

The Group III included plots differed from other on the base of low nitrogen and moisture levels and more acidic reaction of podzolic soil. These habitats belong to pine boreal forest type. Reedgrass (Calamagrostis epigejos (L.) Roth) pine forest (Pn38) and fern (Pteridium aquilinum (L.) Kuhn) pine forests (Pn26) have very similar environmental conditions. Although, reedgrass pine forest has slightly higher degree of nitrogen and moisture. Insignificant increasing of the projective cover of E. angustifolium at second year of study is explained by dieback of forest stand and by increase of light level in these habitats in 2012. More upper-right position of plot Pn27 in the DCA diagram is explained by more xerophytic conditions here. So we can suggest that the lichen pine forest was in this area at pre-fire period. This habitat has a more acidic, dry and nutrient-poor soil conditions. Character of vegetation recovery at plot Pn27 significantly differs from other plots of Group III despite to their similarity on the base of species composition of forest stand. In case of the plot Pn27, slow simultaneous increase of projective cover for both E. angustifolium and secondary growth trees have been observed after active crown fire in 2010. In contrast to other habitats, plot Pn27 is differed by the highest projective cover of $E$. angustifolium with its relatively high vitality as well as by low vitality (lower height,

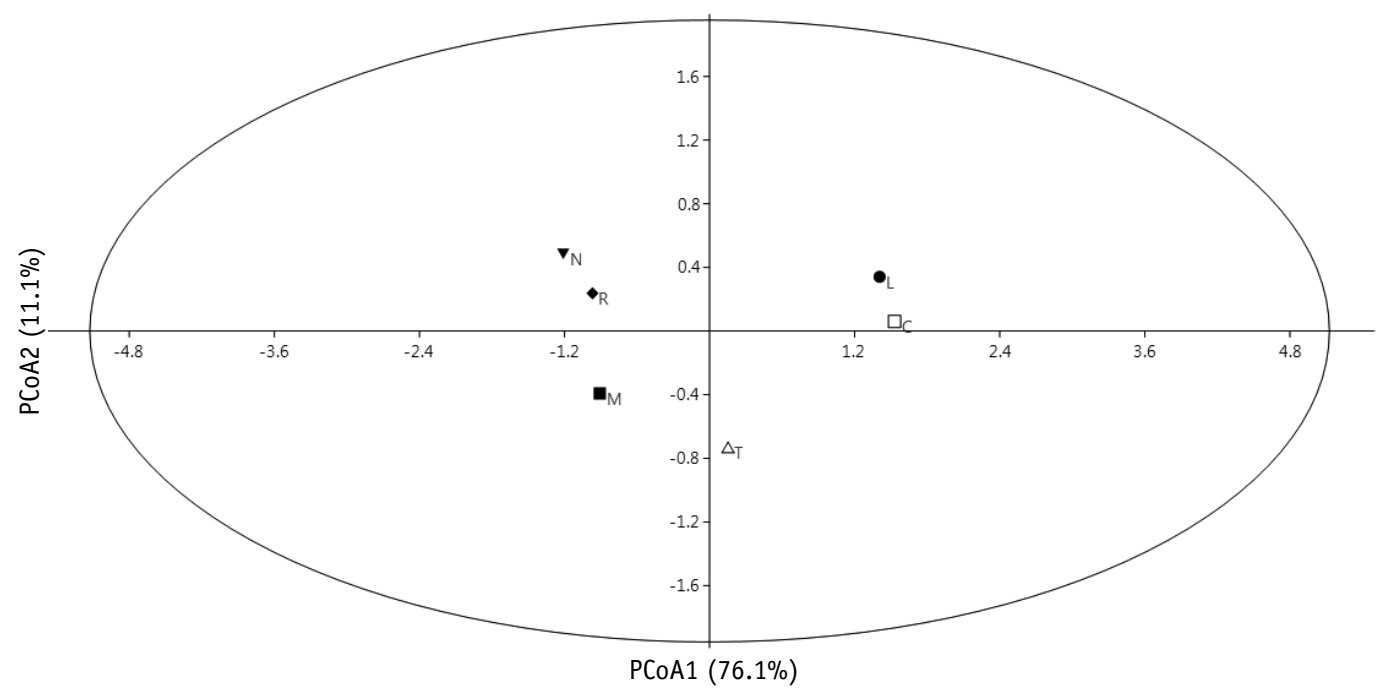

Figure 5. Ordination scheme showing correlation of mean Ellenberg's indicator values for environmental factors at tested forest plots at the southern boundary of the taiga zone. Symbols: $\mathrm{L}$ - light, $\mathrm{T}$ temperature, $\mathrm{C}$ - continentality, $\mathrm{M}$ - soil moisture, $\mathrm{R}$ - soil $\mathrm{pH}, \mathrm{N}$ - soil nitrogen. 
annual dieback percentage) of secondary growth trees. At present the vegetation recovery process conditions in this plot are equal to those at other tested pine forests (Pn26, Pn38) of Group III at first year of study. All these facts are the confirmation of the longest period of re-vegetation in fire-damaged lichen pine forests which are self-perpetuating in absence of fire (Kovaleva, 2014; Morneau \& Payette, 1989).

Among established plots that have not been observed during all study period, Pn29 can be classified to Group II (together with Pn28 and Bt30) on the base of detrened correspondence analysis (DCA) of environmental factors. Completely isolated position of plots Pn07 and Pn40 in the ordination scheme is substantially defined by the most nitrogen-poor and acidic soil conditions due to the high abundance of marsh species (e.g., Sphagnum sp., Eriophorum vaginatum L.). These habitats can be considered as yet other group of forest habitat similar to pine oligotrophic bog forests. Towards a final decision on the distinguishing of such forest habitat group, we need additional long-term ecological investigations.

\section{Conclusion}

Ellenberg's indicator values can be considered as an appropriate system to relate observed variations in flora and vegetation of a given fire-damaged habitat to variations of environmental factors, and to further compare data from different sites. Usually, scientists concentrate their attention in relation of edaphic characteristics (moisture, $\mathrm{pH}$ and fertility). We found that some of climatic EIVs (light and temperature) also can be successfully used in phytoindication of fire-damaged habitats. Nitrogen, moisture and $\mathrm{pH}$ are most important environmental factors determining differences between habitat conditions in firedamaged forest ecosystems at the southern boundary of the taiga zone.
Depending on the environmental factors of given habitat, several groups of firedamaged habitats were defined. This differntiation is considerably correlated with data on the abundance dynamics for main components of the post-fire re-vegetation (E. angustifolium and secondary growth trees). Thus, EIVs can be used to predict the character of the post-fire vegetation recovery in forest habitats before fire influence. No significant differences were found in EIVs amongst different years of study within each tested plot. Hence, the vegetation recovery strategy in each given habitat can be identified in the first year after the fire influence.

In contrast to species forming forest stand, plants of herb-shrub layer (including undergrowth of secondary growth trees) are the most important to define environmental status of a given habitat and its recovery strategy after the fire influence. These are the most sensitive components of forest ecosystems indicating differences in environmental conditions of habitats at the southern boundary of the taiga zone.

Acknowledgements. We are indebted to Dmitriy I. Bashmakov for his valuable comments on the manuscript and language proofreading. We are grateful to anonymous Reviewer for careful attention to the manuscript, advices, and valuable comments which helped to improve the quality of the article. This work was supported by the Ministry of Education and Science of Russia under project No 6.783.2014K.

\section{References}

Aleksandrova, V.D. 1964. The study of changes of vegetation cover. - Lavrenko, E.M., Korchagina, A.A. (eds.). Field geobotany. Moscow, Leningrad, Nauka, 399-447. (In Russian).

Bayanov, N.G. 2015. Climate changes of the northwest of Mordovia during the period of existence of the Mordovia Reserve according to the meteorological observations in Temnikov. Proceedings of the Mordovia State Nature Reserve, 14, 212-219. (In Russian). 
BC Wildfire Service. 2015. Fire Rank. [WWW document]. - URL http://bcwildfire.ca/FightingWildfire/firerank.htm [Accessed 3 April 2016].

Böhling, N., Greuter, W., Raus, T. 2002. Indicator values for vascular plants in the Southern Aegean (Greece). - Braun-Blanquetia, 32, 1-109.

Bond, W.J., Wilgen, B.W. (eds.). 1996. Fire and Plants. London, Chapman \& Hall. 263 pp.

Diekmann, M. 2003. Species indicator values as an important tool in applied plant ecology: a review. - Basic and Applied Ecology, 4, 493-506.

Ellenberg, H., Weber, H.E., Düll, R., Wirth, V., Werner, W. 2001. Pointer values of plants in Central Europe. 3 edition. (Zeigerwerte von Pflanzen in Mitteleuropa. 3. Auflage). - Scripta Geobotanica, 18, 1-261. (In German).

Godefroid, S., Dana, E.D. 2007. Can Ellenberg's indicator values for Mediterranean plants be used outside their region of definition? - Journal of Biogeography, 34, 62-68.

Gromtsev, A. (ed.). 2000. Landscape ecology of boreal forests: theoretical and applied aspects. Petrozavodsk, Karelskiy Nauchny Tsentr RAN. (In Russian).

Hammer, Ø., Harper, D.A.T., Ryan, P.D. 2001. PAST: Paleontological statistics software package for education and data analysis. - Palaeontologia Electronica, 4(1), 9.

Hill, M.O., Mountford, J.O., Roy, D.B., Bunce, R.G.H. (eds.). 1999. Ellenberg's indicator values for British plants. ECOFACT, Vol. 2: Technical Annex. Institute of Terrestrial Ecology, Abbots Ripton. 46 pp.

Hytteborn, H., Maslov, A.A., Nazimova, D.I., Rysin, L.P. 2005. Boreal forests of Eurasia. - Andersson, F.A. (ed.). Coniferous forests. Amsterdam, Elsevier, 23-100.

Karami, A., Sefidi, K., Feghhi, J., Mohadjer, M.R.M. 2012. Spatial distribution of regeneration patches in old growth oriental beech forests in northern Iran. - Forestry Studies / Metsanduslikud Uurimused, 57, 5-15.

Khapugin, A.A., Vargot, E.V., Chugunov, G.G., Shugaev, N.I. 2012. About changes in the vegetation cover of forests of different types after wildfires in the Mordovia State Nature Reserve. - Proceedings of the Mordovia State Nature Reserve, 10, 309-315. (In Russian).

Kovaleva, N.M. 2014. Postfire recovery of the ground cover in pine forests of the Lower Angara Region. - Contemporary Problems of Ecology, 7(3), 338-344.

Kuznetsov, N.I. 2014. The conditions of existence and main features of the vegetation cover structure on the territory of Mordovia State Reserve. 1939 year. - Proceedings of the Mordovia State Nature Reserve, 12, 79-195. (In Russian).

Lavorel, S., Flannigan, M.D., Lambin, E.F., Scholes, M.C. 2007. Vulnerability of land systems to fire: Interactions among humans, climate, the atmosphere, and ecosystems. - Mitigation and Adaptation Strategies for Global Change, 12(1), 33-53.
Lentile, L.B., Morgan, P., Hudak, A.T., Bobbitt, M.J., Lewis, S.A., Smith, A.M.S., Robichaud, P.R. 2007. Post-fire burn severity and vegetation response following eight large wildfires across the western United States. - Fire Ecology, 3(1), 91-108.

Morneau, C., Payette, S. 1989. Postfire lichenspruce woodland recovery at the limit of the boreal forest in northern Quebec. - Canadian Journal of Botany, 67(9), 2770-2782.

Nowak, S., Kershaw, G.P., Kershaw, L.J. 2002. Plant diversity and cover after wildfire on anthropogenically disturbed and undisturbed sites in subarctic upland Picea mariana forest. Arctic, 55, 269-280.

Pignatti, S., Menegoni, P., Pietrosanti, S. 2005. Bioindication through the vascular plants. Indicator values according to Ellenberg (Zeigerwerte) for the species of the flora of Italy. (Biondicazione attraverso le piante vascolari. Valori di indicazione secondo Ellenberg (Zeigerwerte) per le specie della Flora d'Italia). Braun-Blanquetia, 39, 1-97. (In Italian).

Ruokolainen, L., Salo, K. 2006. The succession of boreal forest vegetation during ten years after slash-burning in Koli National Park, eastern Finland. - Annales Botanici Fennici, 43, 363-378.

Ryan, K.C. 2002. Dynamic interactions between forest structure and fire behavior in boreal ecosystems. - Silva Fennica, 36, 13-39.

Seregin, A.P. 2014. Further east: eutrophication as a major threat to the flora of Vladimir Oblast, Russia. - Environmental Science and Pollution Research, 21, 12883-12897.

Steffen, W., Persson, A., Deutsch, L., Zalasiewicz, J., Williams, M., Richardson, K., Crumley, C., Crutzen, P., Folke, C., Gordon, L., Molina, M., Ramanathan, V., Rockström, J., Scheffer, M., Schellnhuber, H.J., Svedin, U. 2011. The anthropocene: from global change to planetary stewardship. - Ambio, 40, 739-761.

Summers, W.T., Coloff, S.G., Conard, S.G. 2011. Fire Histroy and Climate Change, Joint Fire Science Program, Project 09-2-01-09, 190 p.

ter Braak, C.J.F., Gremmen, N.J.M. 1987. Ecological amplitudes of plant species and the internal consistency of Ellenberg's indicator values for moisture. - Vegetatio, 69, 79-87.

Tereshkin, I.S., Tereshkina, L.V. 2006. Vegetation of the Mordovia Reserve. Successive series of the successions. - Proceedings of the Mordovia State Nature Reserve, 7, 186-287. (In Russian).

Tinner, W., Conedera, M., Gobet, E., Hubschmid, P., Wehrli, M., Ammann, B. 2000. A palaeoecological attempt to classify fire sensitivity of trees in the southern Alps. - The Holocene, 10(5), 565-574.

Turner, M.G., Hargrove, W.W., Gardner, R.H., Romme, W.H. 1994. Effects of fire on landscape heterogeneity in Yellowstone National Park, Wyoming. - Journal of Vegetation Science, 5, 731-742. 
Ulanova, N.G. 2000. The effects of windthrow on forests at different spatial scales: a review. Forest Ecology and Management, 135(1-3), 155-167.

Vacchiano, G., Lonati, M., Berretti, R., Motta, R. 2015. Drivers of Pinus sylvestris L. regeneration following small, high-severity fire in a dry, inner-alpine valley. - Plant Biosystems, 149(2), 354-363.

Viewegh, J., Kusbach, A., Mikeska, M. 2003. Czech forest ecosystem classification. - Journal of Forest Science, 49, 85-93.

Walter, H., Breckle, S.-W. (eds.). 1999. Vegetation and climatic zones. 7 edition. (Vegetation und
Klimazonen. 7. Auflage). Ulmer Verlag, Stuttgart. 544 pp. (In German).

Zelený, D., Schaffers, A.P. 2012. Too good to be true: pitfalls of using mean Ellenberg indicator values in vegetation analyses. - Journal of Vegetation Science, 23, 419-431.

Zhang, X., Liu, Z., Bing, Y., Zhu, B., Trung, L.N., Chen, K. 2014. Dissimilation of soil humus in forest with pure stands and its relationship with other bio-chemical properties in the semiarid windy region of the Loess Plateau, China. Forestry Studies / Metsanduslikud Uurimused, 60, 24-33. 